\title{
Features of the formation of the St. Petersburg agglomeration by the beginning of the $X X$ century
}

\author{
Sergey Sementsov ${ }^{1, *}$, Svetozar Zavarikhin ${ }^{1}$, Yuryi Kurbatov ${ }^{1}$, and Yuryi Pukharenko ${ }^{1}$ \\ ${ }^{1}$ Saint Petersburg State University of Architecture and Civil Engineering, 90005, Saint Petersburg, \\ Russia
}

\begin{abstract}
The study of the Russian historical St. Petersburg agglomeration at all stages from its foundation (from 1703) until the final imperial stage (1917) required the use of complex functional, urbanplanning and landscape, socio-economic, environmental, transport and communication analysis on the basis of data from archives, historical cartography and iconography. The main results were the conclusions that during the XVIII - early XX centuries, there was a crystallization of a huge agglomeration around the city of St. Petersburg, which included three belts: "external", "middle", "nearby", which spatially extended from Yaroslavl (in Central Russia) to Riga (in the Baltic). The paper discusses the features of the formation of the "nearby belt" of agglomeration in the initial (1703 - January 1725) and in the final (1901-1916) development periods. The study revealed a significant role of special types of objects in these processes - estates of the aristocratic society and "garden cities" that provided a belt (around St. Petersburg and the largest settlements and complexes), linear (along radial and ring highways), and nodal (around individual large settlements) construction, spreading in the latitudinal direction from Narva and Ivangorod to the mouth of the Syas river, and in the meridian direction - from Vyborg to the city of Luga. Within the boundaries of this agglomeration zone, four sub-agglomerations had begun to emerge since the $1710 \mathrm{~s}$ and have fully formed by the $1910 \mathrm{~s}$. The materials of the paper can be useful both for historians of urban planning and for modern urbanists.
\end{abstract}

\section{Introduction}

The study of the laws of emergence and subsequent development of agglomerations in different regions of Russia and many countries of the world is of great importance for modern urban planning. Agglomeration research is carried out by a wide range of specialists - urban planners, urbanists, landscape architects, economic geographers, urban regionalists, specialists in social behavior, etc. They connect the problems of urban formation with the laws of directing the creation of man-made landscapes. Indeed, each

\footnotetext{
* Corresponding author: s.sementsov@,mail.ru
} 
agglomeration is a completely harmonious combination of different environmental landscape systems. [1- 5].

Among the agglomeration (megacities, conurbations), such agglomerations that do not fit into the generally established "rules" are of particular interest. Such agglomerations include the historical metropolitan St. Petersburg agglomeration. Moreover, with an exact date of birth (1703) and with obvious signs of the formation of the whole environment on the basis of "regularity" (since 1712, on the basis of D. Trezzini's projects) and "ensemble" (since 1716, according to the proposals of J. -B.-A. Le Blond). These ideas were fundamental, specially prescribed in royal decrees, necessarily implemented not only at the very beginning of the formation of agglomeration under Peter the Great (in 1703-1724), but also during the XVIII - early XX centuries on the territory of the metropolitan city itself and in its suburbs. For more than 200 years, a unique "regular", ideal in terms of its spatial and compositional principles agglomeration has developed around St. Petersburg, which has no analogues in world architecture. The development of St. Petersburg and its agglomeration in our time also attracts the attention of modern urban planners [6;7]. A brief description of some features of the agglomeration, entrenched up to 1917 , became the basis of this paper.

\section{Methods}

The study of the historical development of large man-made landscape formations - cities and agglomerations, requires parallel consideration of a wide range of sources. This paper uses the results of studying collections of historical cartographic and written materials from the collections of St. Petersburg, Stockholm, Berlin and other cities, published works of historians and specialists in related professions, as well as numerous legislative acts of urban development. Such a parallel examination of historical cartographic and archival materials helped to identify patterns of the development of both St. Petersburg itself and several zones of suburban territories within the framework of the St. Petersburg agglomeration over the decades of the XVIII - early XX centuries.

\section{Results}

\subsection{3 - January 1725. The foundation of St. Petersburg and the St. Petersburg agglomeration under Peter the Great}

1703 - January 1725 - the years of the beginning of the imperial period of development of the metropolitan St. Petersburg and the metropolitan St. Petersburg agglomeration formed around it. The almost daily concern of the Tsar (since 1721 - Emperor) Peter the Great was the creation of St. Petersburg and the development of the territories surrounding it. In May 1703, a "regular" earth-and-timber fortress called "Saint-Peters-Burg" was founded in the delta of the river Neva, and with it - an attached settlement, which gradually became the basis of the future vast metropolitan city.

Since 1703, in parallel with the hostilities between the Russian and Swedish troops, the development of the original Russian territories that were recaptured from the Swedes took place (these territories were recaptured by Sweden from Russia in the 1580s - 1610s) [8]. At the same time, a system of diverse territorial and functional objects arose, gradually uniting the ancient Russian and conquered Swedish objects, including maintaining the numerous system of fortresses (trenches, redoubts) and placing Russian regiments and units, creating and developing various types of industries and manufactories (casting and metalworking, woodworking, shipbuilding, production of building materials, etc.), 
accelerated development of land and water transport communications, reconstruction of existing and construction of new towns, settlements, villages.

These territories returned to Russia in 1708-1710 were combined with indigenous Russian spaces and together became the St. Petersburg Governorate. According to the Provincial Reform of Peter the Great (1708), the Ingermanland (from 1710 - St. Petersburg) governorate was formed, which included the largest territories from Yaroslavl to Narva, with 29 cities and an area of 490,000 square $\mathrm{km}$, which is spatially significantly larger than the area of modern Germany (357,021 sq. km), Denmark (43,094 sq. km), the Netherlands (41,526 sq. km), Belgium (30,528 sq. km) combined [9].

But on this territory with several zones and belts of spatially functional nodes, there was still no center of the governorate itself (!). Surprisingly, it must be noted: the governorate was defined and existed for some time without the provincial center, without the provincial city. Although candidates for the provincial status could be large ancient cities: Novgorod, Pskov, Yaroslavl, Kostroma, etc. But not a small settlement near the fortress in the Neva Delta. Thus, up to 1707-1708, the emerging St. Petersburg with its fortress and suburban development of a clearly non-urban kind could not claim central roles. Only in 1708 the gradual crystallization of its center took place in the governorate for various reasons, the emerging St. Petersburg became such a center, the geopolitical energy of which enabled it to obtain the potential of this boundless territory. At first (in 1708-1710), this settlement (village, fortress suburb) turned into the center of the governorate - into a provincial city, from 1712 - into the capital of the Russian state, from 1721 - into the capital of the Russian Empire. And each new transformation of his status caused a radical reconstruction of its planning, functional and social structure. And also significant changes in the structure of the agglomeration that arose around it (i.e., zones, objects and territories directly related to the daily life of St. Petersburg).

A careful study of the complexes of archival (published and unpublished) data that make it possible to identify multiple economic lines of attraction and interaction between different territories of Russia and St. Petersburg (up to daily economic relationships) helped establish that three agglomeration zones began to appear around St. Petersburg by 1725: "nearby belt" (in the closer circle around St. Petersburg - from Narva and Yamburg in the west to Olonets in the east, from Sestroretsk and Mednyy Zavod in the north to Volosov in the south), "middle belt" (within the borders of the St. Petersburg Governorate - from Gdov and Pskov in the west to Yaroslavl, Kargopol, Petrozavodsk in the east, from Povenets in the north to Rzheva Vladimirova in the south), "external belt" (outside the borders of St. Petersburg Governorate - including major centers - Arkhangelsk in the north, in the east Vologda, in the south - Vladimir and Moscow ...) (Ill. 1; 2). 


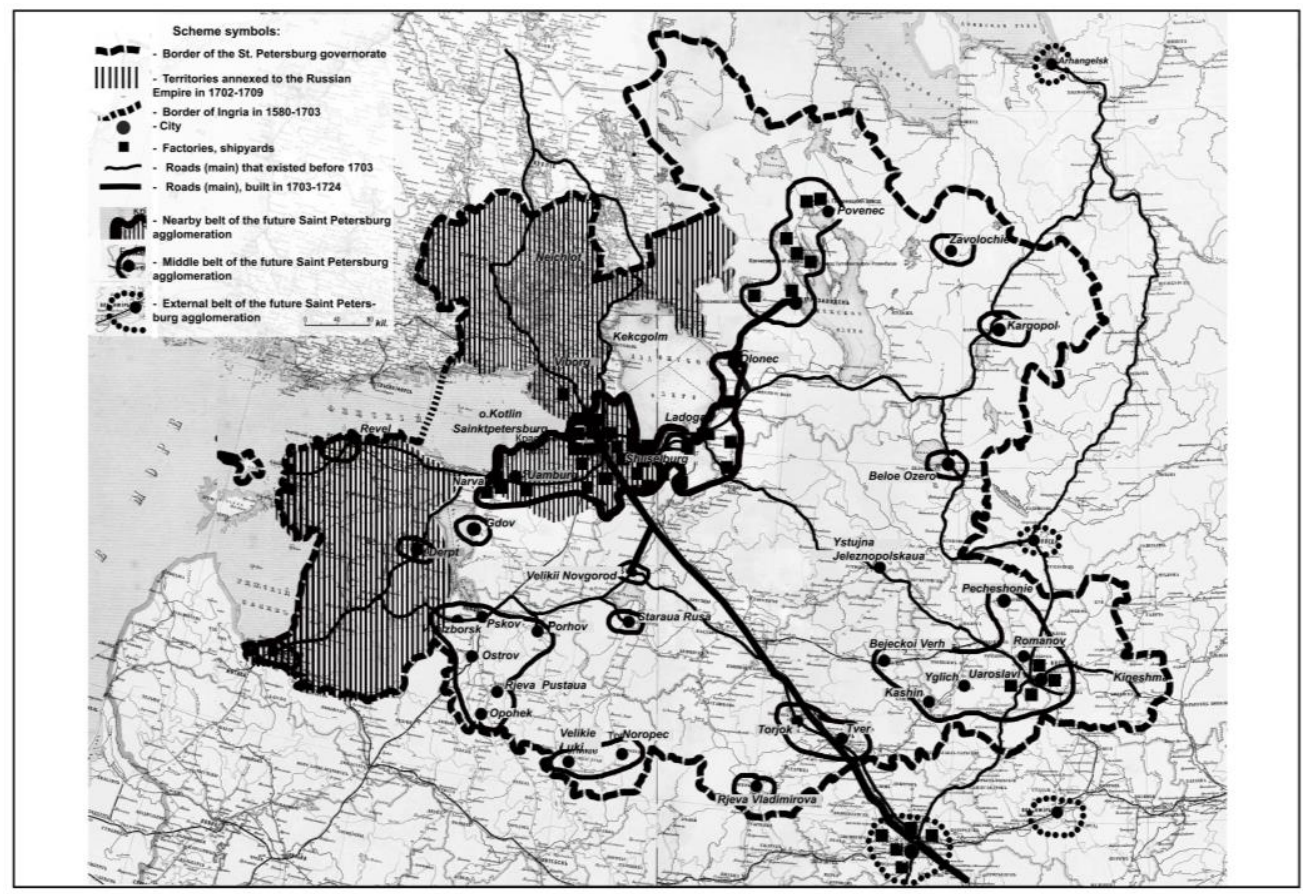

Illustration 1. 1710-1725 yy. The largest multifunctional centers in the territory of the Saint Petersburg Governorate. Nearby and middle belts of the future Saint PetersReconstruction: Sergey V. Sementsov, Ekaterina V. Skogoreva, Nadezhda A. Akulova. [The scheme is made on the topographic map of 1840]

Fig1. 1710-1725 year. The largest multifunctional centers in the territory of the Saint Petersburg Governorate. Nearby and middle belts of the future Saint Petersburg agglomeration.

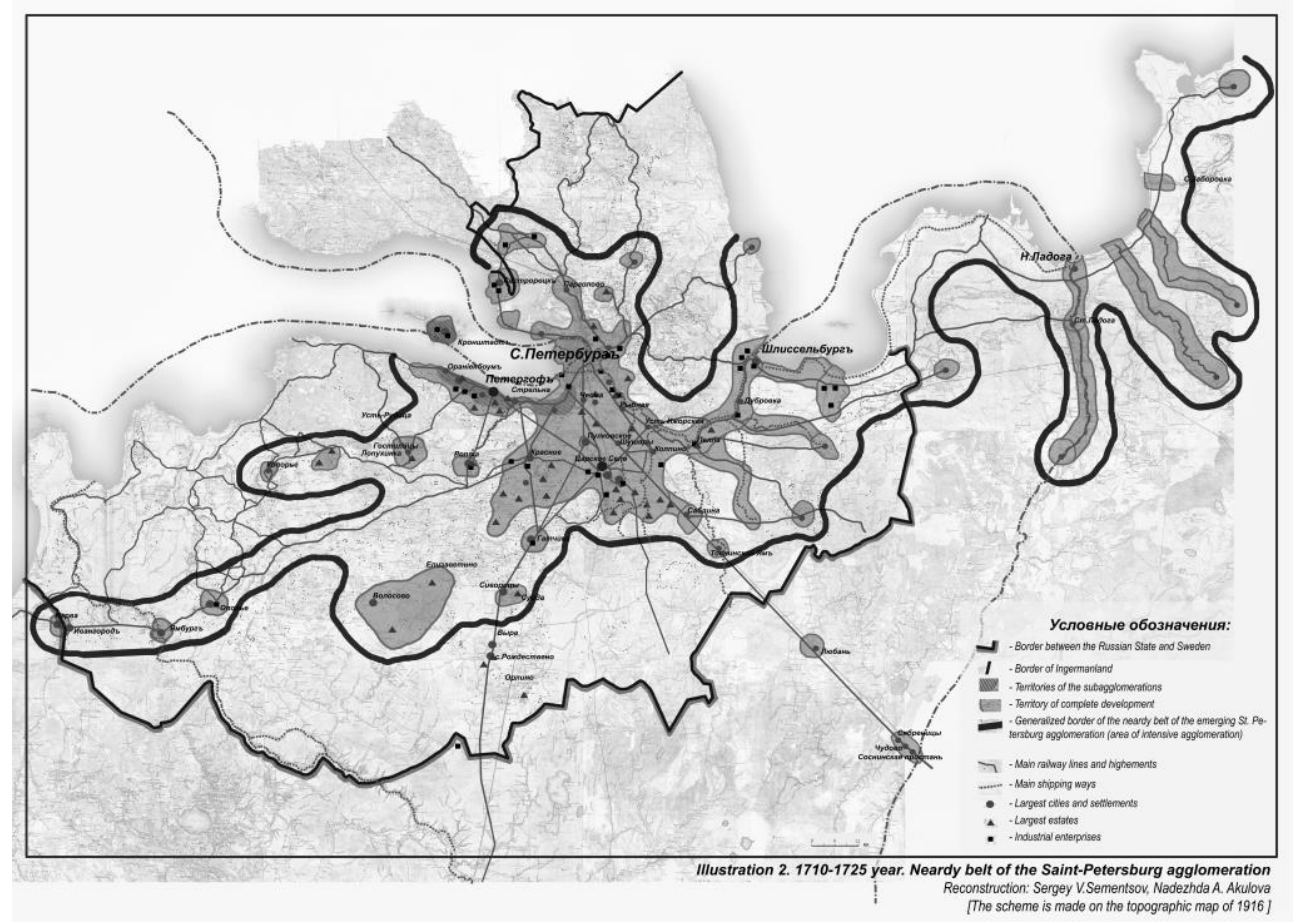

Fig. 2. 1710-1725 year. Nearby belt of Saint Petersburg agglomeration. 
Huge suburban areas around the rapidly built St. Petersburg were reclaimed in a coordinated manner, with a total area of hundreds of square kilometres, with the parallel creation of many compositional nodes of the largest ensemble development on this unified territory. This scope of unified urban development actions was not in other European countries. With the development of the St. Petersburg agglomeration, following was created consciously (hundreds of decrees of Peter the Great speak of this), simultaneously and very quickly:

- the metropolitan city of St. Petersburg with its nearby suburbs and nearby summer cottage (estate) zones on many islands and territories of the Neva Delta - ideal in its general composition and in the unity of "regularity" and "ensemble". Occupied territory - 15-20 km in diameter;

- the system of royal (imperial) city and suburban residences and estates;

- vast areas and zones of suburbs formed by systems of country estates of the aristocratic society, nobles, merchants, artisans, in the unity of "regularity" and "ensemble", compositionally "ideal" themselves and forming regular rectangular, star-shaped and radial compositions. This system covered spaces with a diameter of more than $150 \mathrm{~km}$;

- fortification system, including a large number of fortresses, redoubts, forts, and defensive lines "ideal" in form. This system has spatially spread to almost $100 \mathrm{~km}$ in diameter;

- a system of diverse industrial facilities: shipbuilding (with many shipyards and auxiliary industries), foundries and metalworking (starting from ore mining, metal production, creation of weapons, ship rigging, supplies for troops, etc.), production of building materials (brick, tile and glass plants, stone quarries, production of limestone, lime, etc.), woodworking (harvesting of firewood and wood for construction, production of lumber, etc.), manufactory for the production of foodstuffs (flour, bread, starch, sugar, vodka, etc.), manufactory for the production of household goods (leather, lace, fabric, cloth, etc.);

- transport system (land and water) that provides optimal territorial connections between all spatial elements. Partly on the basis of ancient pre-Petersburg roads, but mainly by creating new lines and roads. A system of navigable waterways-channels was also formed (fully and partially implemented);

- a system of visual, symbolic, iconic, general cultural dominants in the entire developed space, spatially uniting hundreds of elements.

When analyzing historical processes in the territories of the emerging St. Petersburg Governorate, the following qualitative stages can be distinguished:

- 1703-1711 years. The formation of a unified administrative and economic territory of the St. Petersburg Governorate in its large-scale borders and the gradual "crystallization" of St. Petersburg from an outer settlement (forstadt) to the level of the provincial capital.

- 1712-1721 years. Crystallization and socio-political awareness of the structure of the St. Petersburg Governorate as the capital of the Russian state, then the capital of the Russian Empire. Preservation of the territorial scope of the St. Petersburg Governorate, the beginning of the processes of turning its most important nodes into the primary nodal elements of the metropolitan St. Petersburg agglomeration. Conducting large-scale reconstructions of St. Petersburg and many surrounding cities and settlements (in 1712$1715,1716-1718,1719-1721)$ according to the principles of "regularity" and "ensemble", with the transformation of St. Petersburg into an "ideal city".

- 1722-1724 years. The birth of a full-fledged metropolitan St. Petersburg agglomeration (with a spatial scope of more than 300x150 km), structurally and territorially uniting the core city of St. Petersburg, a system of external ("outbound") roads coming out of it, and nodes and zones already appearing on these roads. The beginning of the 
transformation of the emerging agglomeration into an "ideal agglomeration" based on the principles of "regularity" (with straight and geometrically clear roads and a rectangular layout of cities and villages). At the same time, in the same years, "sub-agglomerations" began to appear in the structure of the "nearby belt" of the St. Petersburg agglomeration, which began to functionally focus not only on the main city of the agglomeration - St. Petersburg, but also on the most important objects in these zones themselves: 1) Kronstadt with associated forts (with a concentrating role - the "sub-center" - the Kronstadt fortress); 2) Oranienbaum-Peterhof-Strelna (with the "sub-center" - imperial Peterhof) $[10 ; 11]$.

\subsection{1-1917. Some features of the development of the metropolitan St. Petersburg agglomeration by the beginning of the $\mathrm{XX}$ century}

1901-1917 - the years of the completion of the imperial period of development of metropolitan St. Petersburg and the metropolitan St. Petersburg agglomeration formed around it. By the beginning of the XX century several significant changes in the territorial development of the St. Petersburg Governorate can be noted.

Since the 1800 s, the total territory of the governorate was significantly reduced.

In parallel, from the mid-1840s, the construction of many railroads began around St. Petersburg, which significantly changed the network of roads (highways, tracts, regional roads, railways) and water ways (along rivers, lakes, the Baltic Sea and its bays).

By the 1900s, a single spatial, functional and compositional system of the entire agglomeration united:

- the metropolitan city of St. Petersburg with its nearby suburbs and nearby summer cottage (estate) zones on many islands and territories of the Neva Delta is ideal in its general composition and in the unity of "regularity" and "ensemble". Occupied area - 40-60 $\mathrm{km}$ in diameter;

- the system of royal (imperial) city and suburban residences and estates;

- the vast areas and zones of the suburbs formed by the systems of suburban estates of the aristocratic society in the unity of their compositional "regularity" and "ensemble". This system covered the entire province, capturing the zones of other provinces, especially along the "outbound roads" and extending over the territory with a diameter of more than 200$250 \mathrm{~km}$;

- fortification system with an undoubted center - the Kronstadt fortress, sub-centers - a system of forts, historical (ancient Russian) fortresses, modern redoubts, defensive lines. This system has spatially spread almost $100-150 \mathrm{~km}$ in diameter;

- a system of a very developed network of diverse industrial facilities, from grandiose (for example, the Admiralty Obukhov factories) to small factories of dozens of functional divisions. By the beginning of XX century, only the Town Hall of St. Petersburg had more than 80 craft workshops "responsible" for their core industries;

- transport system (land and water) that provides optimal territorial connections between all spatial elements. A system of navigable waterways-channels was also formed (fully and partially implemented). By this time, agglomerations and airdromes began to be created in the territories as elements of the emerging air system;

- a system of visual, symbolic, iconic, general cultural dominants in the entire developed space, spatially uniting hundreds of elements.

In preparing the paper, the authors drew attention to 2 components of this multifunctional and multicomponent unity: the system (network) of estates of the aristocratic society and the system (network) of a new suburban element - cottage villages and garden cities.

Estates of the aristocratic society. The system of "estates of the aristocratic society" began to form even under Peter the Great (from 1710-1711). Among more than 2000 noble 
estates of the governorate by the 1910s, there were no less than 271 estates of the aristocratic society - this shows the amazing density of such estates precisely in the metropolitan governorate (!). "Estates of the aristocratic society" ("Nearby estates of the aristocratic society") had significant features. The estates that arose and developed around St. Petersburg are a special type of estates of representatives of the Russian aristocracy, formed around St. Petersburg [12].

Representatives of the 4 highest ranks socially belonged to the aristocratic society (according to the "Table of Ranks" approved by the Highest Act of Peter the Great of January 24, 1722) [13] and according to the Manifesto of Succession (introduced by Paul the First as "Establishment of the Imperial Family Name" of April 5, 1797) [14] - members of the Imperial family, military ranks - from generals and admirals to field marshals, civil ranks - highest ranks of the Collegiums and, then, the Ministries, as well as the Imperial Court. Such estates differed from hundreds and thousands of ordinary noble estates in that they were significantly larger - more than 5.0 hectares (but more often tens, even hundreds hectares), and also included in their ensembles not only many different service and auxiliary buildings (vegetable and fruit greenhouses, blacksmith and carpentry workshops, oil mills, milk houses and distilleries, etc.), but also numerous special (obviously not functional, but necessarily prestigious) elements - "Friendship Temples", "Islands of Love", "Parnassus Hills", greenhouses for the cultivation of exotic plants, stables for especially thoroughbred horses and cattle, gardens and parks in a particularly artistic design, ponds and lakes with special landscape outlines, complex systems of paths and viewpoints, etc.

"Estates of the aristocratic society" were noted on the territory of the modern center of St. Petersburg (these were the oldest estates, "absorbed" by the expanding center of the capital decades later). They were located in a continuous belt in four nearby suburban districts around St. Petersburg, as well as large local zones of smaller estates around central estates for those territories - in the four distant counties of the governorate, and in the adjoining districts of other governorates - Novgorod and Vyborg (Fig. 3). 


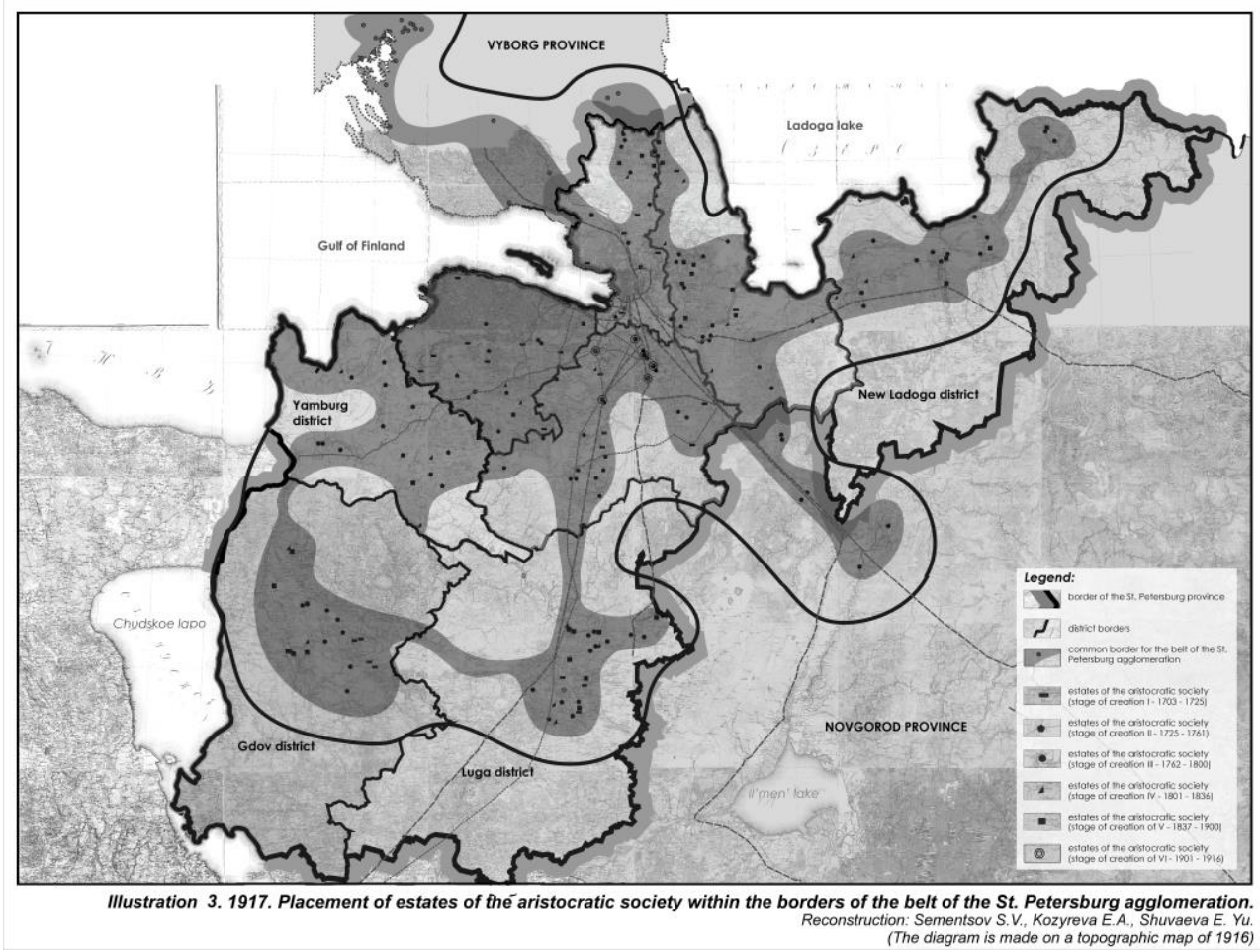

Fig. 3. 1917 year. Placement of estates of the aristocratic society within the borders of the belt of the Saint Petersburg agglomeration.

Complexes of cottage villages and "garden cities". Construction of cottages around St. Petersburg throughout the XIX century acquired special qualities by the beginning of the 1900s. Development of railway lines throughout the XIX century led to the fact that new territories were located in the accessibility zones located farther from the borders of St. Petersburg (since 1914 - Petrograd), ensuring the formation of stable loci for new summer cottage construction. At the same time, the nearby belt of agglomeration expanded significantly along the outbound railway lines to Narva - Ivan-Gorod; Luga; ChudovoSosninskaya pier on the Volkhov river. For St. Petersburg and in general for the entire St. Petersburg agglomeration in the late XIX - early XX centuries, it is possible to note 3 rings of such a summer house construction (as one of the new elements and factors in the development of the entire agglomeration). Moreover, the cottage settlements themselves acquired the stable characteristics of year-round "garden cities" with a service system (schools, shops, theatres, sports facilities, churches, etc.), their own transport connection system (up to roads for horse trams and railways), landscaping (sidewalks and highways, lighting, bridges, etc.). All this was very reminiscent of the tendency to create settlements of a special type: describing settlements in the terminology of the ideas of "garden cities": "garden suburbs", "garden districts", "garden cottage villages" [15; 16; 17].

At the same time, the processes of differentiation of the "Nearby belt" of the St. Petersburg agglomeration into three zones were going on:

The first zone of the Nearby belt. In the peripheral territories of the metropolitan city (in the zone of its administrative border and outside it) - the zone of "garden districts", formed along the routes and within the limits of public transport accessibility. 
The second zone of the Nearby belt. Separate "garden suburbs" and their vast surroundings. They were located a little further from the city in almost all directions along the railways and highways, and with an equally clear regular planning system, with a high level of landscaping and cultural and communal services, providing comfortable housing for residents living in these suburbs and coming daily to work in St. Petersburg. In the framework of the so-called daily pendulum availability.

The third zone of the Nearby belt. Here, settlements, large centers and vast separate belts of cottage villages existed and developed simultaneously. Farther away from the city, grandiose, many-kilometre-long groups of cottage villages were formed along with the railway lines, main highway "outbound" routes and shipping routes of St. Petersburg. By the beginning of the XX century, agglomeration lines spread along these "outbound" transport arteries, reaching Narva - Ivan-Gorod, Luga, Chudovo-Sosninskaya pier. Almost all new settlements were built on the principles of "cottage villages - gardens" and taking into account the tradition of the St. Petersburg population to go to the cottages, in conditions of seasonal migration (mass departure to the cottages: in late May - early June, mass return to St. Petersburg during the autumn-winter season: at the end of August September) (Fig. 4).

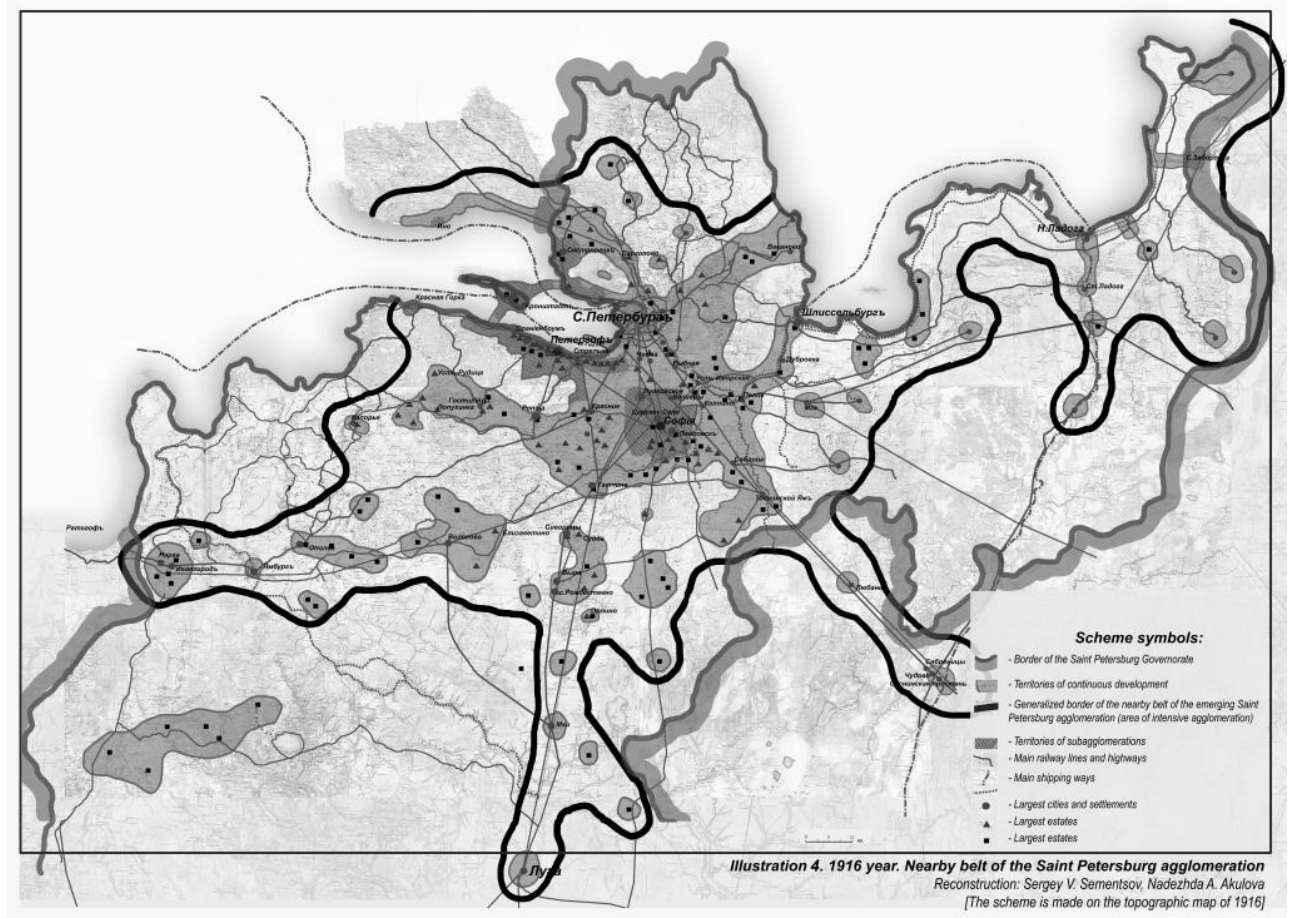

Fig. 4. 1916 year. Nearby belt of the Saint Petersburg agglomeration.

Such a concentration of not only production, but also recreation zones around St. Petersburg shows significant functional, spatial and landscape changes in the developing St. Petersburg agglomeration by the beginning of the XX century [18].

But it is also significant fact that, throughout the XVIII - early XX centuries, within the framework of the St. Petersburg agglomeration, processes of its hierarchical structuring and the final formation of four "sub-agglomerations" was underway in parallel: 1) Kronstadt (Kronstadt and forts, from the beginning of the XVIII century); 2) Peterhofskaya (Strelna Peterhof - Oranienbaum, from the beginning of the XVIII century), 3) Tsarskoye Selo 
(Tsarskoye Selo - Pavlovsk - Tsarskaya Slavyanka, from the end of the XVIII century), 4) Sestroretsk (from the end of the XIX century).

\section{Discussion}

This paper shows the features of changes in the metropolitan St. Petersburg agglomeration at two critical stages: at the beginning of its development (1703-January 1725) and during its forced decay (1901-1917). These periods, which are fundamental for understanding the dynamics of the development of the St. Petersburg agglomeration, clearly show the extraordinary processes that took place in the vast territories around St. Petersburg and the development processes that were forcibly stopped in 1917. Moreover, for the large population of the capital, who continued to have a seasonal lifestyle (summer - cottage season, winter - life in the city itself), new zones and belts of cottage construction were formed by the beginning of the XX century, which gradually turned into permanent settlements. At the same time, the nearby belt of the agglomeration significantly expanded along the outbound railway directions to Narva - Ivan-Gorod; Luga; Chudovo-Sosninskaya pier on the Volkhov river. By the beginning of the XX century, 4 "sub-agglomerations" have clearly crystallized in the system of the nearby belt of the St. Petersburg agglomeration: 1). Kronstadt (Kronstadt, sea forts and land fortresses); 2). Peterhof (Strelna - Peterhof - Oranienbaum); 3). Tsarskoye Selo (Tsarskoye Selo - Pavlovsk - Tsarskaya Slavyanka), 4) Sestroretskaya (with a line of cottage villages along the shore of the bay).

\section{Conclusion}

Thus, an analysis of the development processes of the St. Petersburg agglomeration during the XIX - early XX centuries showed a significant expansion of the general borders of the "Nearby belt" of the agglomeration over these decades, including new territories in the southeast, south, southwest. These transformations led to a significant restructuring of the original system of "estates of the aristocratic society", as well as to the massive creation of new functional landscape elements - cottage villages, cottage zones and cottage belts, created on the principles of regular "garden cities" and "garden suburbs" in the territories of the expanding nearby belt of agglomeration. At the same time, there were processes of significant concentration of a number of zones, which began to crystallize in four "subagglomerations".

\section{References}

1. G.A. Isachenko, Window to Europe: History and Landscapes (467, Publishong House of $\mathrm{SpbSU}, \mathrm{SPb}, 1998$ )

2. Ya.V. Kositsky, Architectural and planning development of cities (648, Architecture-S, Moscow, 2005)

3. R. Hehl, Designing the Rural: A Global Countryside in Flux, No. 04, 86, $34-41$ (2016)

4. C. Roskam, Designing the Rural: A Global Countryside in Flux, No. 04, 86, 14 - 19 (2016)

5. G. Tokunova, 12th International Conference "Organization and Traffic Safety Management in Large Cities", 649-652, SPb (2017)

6. D.O. Shvidkovsky, Collection «Architecture in the history of Russian culture», 7, 8-74, KomKniga, Moscow (2007) 
7. Demographia World Urban Areas (Built Up Urban Areas or World Agglomerations). 15th Annual Edition, 125 (2019)

8. S.V. Sementsov, Proceedings of the State Hermitage, LXXVIII, 388-398,: Publishing House of the State Hermitage, SPb (2015)

9. S.V. Sementsov, E.V. Skogoreva, N.A. Akulova, Administrative and territorial division of St. Petersburg and the St. Petersburg Governorate of the XVIII - early XX centuries, 172, SPbGASU, SPb (2014)

10. S. Sementsov, E. Skogoreva, N. Akulova, Administrative-territorial division of St. Petersburg and St. Petersburg province XVIII - beginning of XX century. St. Petersburg: SPSUACE, 172 (2014)

11. S.V. Sementsov, Bulletin of Civil Engineers, Issue. 3 (44), 46-55, SPbGASU, SPb (2014)

12. S.V. Sementsov, N.A. Akulova, Vestnik of the Tomsk State Administrative University, 20, No. 6, Publishing House TGASU, Tomsk (2018)

13. E.A. Kozyreva, Bulletin of Civil Engineers, No. 1 (54), 5-11, SPbGASU, SPb (2016)

14. No. 3890. January 24, 1722. «Table of ranks of all statuses, military, civil and court, which in which class ... », PSZRI, VI, 1720-1722, SPb.: Tip. II Otdbleniya Sobstvennoy Ye.I.V. Kantselyarii, 1830, P. 486-493 (1830)

15. No. 17906. April 5, 1797. «Establishment of the Imperial Family», PSZRI, XXIV, November 6, 1796-1798. SPb.: Tip. II Otdظleniya Sobstvennoy Ye.I.V. Kantselyarii, 1830, P. 525-569 (1830)

16. V.L. Rugge, Proceedings of Higher Educational Institutions. Architecture and construction, No. 5, 180-188 (1961)

17. T. Fritsch, Die Stadt der Zukunft: mit zwei farbigen Tafelnund 14 Text Abbildungen, 45, Leipzig (1896)

18. E. Howard, To-morrow: A Peaceful Path to Reul Reform By E. Howard. London: Swan Sonnenschein \& CO, Ltd. Paternoster Square (1898)

19. Urban planning grandeur of St. Petersburg. 300 years of unified state urban planning activity in St. Petersburg. 1706-2006, p. 64. Exhibition Catalog, Compiler, author of the introductory text andcomments Sergey Sementsov, St. Petersburg (2006) 